\title{
pXRF Sourcing of Obsidian from Pallaucha, Vilcashuaman: Insights into Exchange Patterns in South-Central Peru during the Early Horizon
}

Detección de fuentes de procedencia de la obsidiana de Pallaucha,

Vilcashuamán, mediante pXRF: una visión de los patrones de intercambio en el centro-sur del Perú durante el Horizonte temprano

Détection des sources de provenance de l'obsidienne de Pallaucha

(Vilcashuaman) par pXRF : Un aperçu des modèles d'échange dans le centre-sud du Pérou au cours de l'Horizon Ancien

Edison Mendoza Martínez, Jason Nesbitt, Yuichi Matsumoto, Yuri Cavero Palomino and Michael D. Glascock

\section{(2) OpenEdition}

\section{Journals}

Electronic version

URL: https://journals.openedition.org/bifea/12232

DOI: $10.4000 /$ bifea.12232

ISSN: 2076-5827

\section{Publisher}

Institut Français d'Études Andines

Printed version

Date of publication: 8 December 2020

Number of pages: 255-276

ISSN: 0303-7495

\section{Electronic reference}

Edison Mendoza Martínez, Jason Nesbitt, Yuichi Matsumoto, Yuri Cavero Palomino and Michael D. Glascock, "pXRF Sourcing of Obsidian from Pallaucha, Vilcashuaman: Insights into Exchange Patterns in South-Central Peru during the Early Horizon", Bulletin de l'Institut français d'études andines [Online], 49 (2) | 2020, Online since 25 November 2021, connection on 01 December 2021. URL: http:// journals.openedition.org/bifea/12232 ; DOl: https://doi.org/10.4000/bifea.12232

Les contenus du Bulletin de l'Institut français d'études andines sont mis à disposition selon les termes de la licence Creative Commons Attribution - Pas d'Utilisation Commerciale - Pas de Modification 4.0 International. 


\title{
pXRF Sourcing of Obsidian from Pallaucha, Vilcashuaman: Insights into Exchange Patterns in South-Central Peru during the Early Horizon
}

\author{
Edison Mendoza Martínez* \\ Jason Nesbitt** \\ Yuichi Matsumoto ${ }^{* * *}$ \\ Yuri Cavero Palomino**** \\ Michael D. Glascock $k^{* * * *}$
}

\begin{abstract}
Recent archaeological research demonstrates that the south-central highlands was a region of important sociocultural developments during the Early Horizon (ca. 800-200 BC). One reason for the prominence of this region was the local availability of obsidian, a widely exchanged lithic material. In this paper, we discuss the results of a portable X-ray fluorescence (pXRF) sourcing study of a sample of 26 obsidian artifacts from the site of Pallaucha, an Early Horizon civic ceremonial center located near Vilcashuaman in the Department of Ayacucho, Peru. PXRF analysis demonstrates that the Quispisisa source was the most commonly exploited locality to acquire obsidian at Pallaucha even though other sources were in closer proximity. Our results complement the results of a study of a large sample of obsidian from the nearby, and partially contemporary, civic-ceremonial center of Campanayuq Rumi.
\end{abstract}

Keywords: pXRF, obsidian, exchange and interaction, Paracas, south-central highlands, Peru

* Universidad Nacional San Cristóbal de Huamanga, Ayacucho, Perú.

** Department of Anthropology, Tulane University, New Orleans, USA. E-mail: jnesbitt@tulane.edu.

*** Faculty of Literature and Social Sciences, Yamagata University, Yamagata, Japan.

**** Facultad de Letras y Ciencias Humanas, Universidad Nacional Mayor de San Marcos, Lima, Perú.

${ }^{* * * * *}$ Research Reactor Center, University of Missouri-Columbia, Columbia, USA. 


\title{
Detección de fuentes de procedencia de la obsidiana de Pallaucha, Vilcashuamán, mediante pXRF: una visión de los patrones de intercambio en el centro-sur del Perú durante el Horizonte temprano
}

\begin{abstract}
Resumen
Recientes investigaciones arqueológicas demuestran que la sierra centro-sur experimentó importantes desarrollos socioculturales durante el Horizonte temprano (ca. 800-200 a. C.). Una de las razones de la importancia de esta región fue la disponibilidad local de obsidiana, un material lítico con el que se comercia frecuentemente. En este artículo, presentamos y discutimos los resultados de un estudio de detección de fuentes de obsidiana mediante espectrometría de fluorescencia de rayos X portátil (pXRF) en una muestra de 26 artefactos provenientes del sitio de Pallaucha, un centro cívico-ceremonial del Horizonte temprano ubicado cerca de Vilcashuamán en el departamento de Ayacucho, Perú. El análisis pXRF muestra que la obsidiana de Quispisisa era la más explotada, a pesar de la existencia de otras fuentes en las cercanías de Pallaucha. Este resultado complementa y concuerda con el estudio de la obsidiana obtenida en Campanayuq Rumi, un centro cívico-ceremonial contemporáneo con Pallaucha.
\end{abstract}

Palabras claves: pXRF, obsidiana, intercambio e interacción, Paracas, sierra centro-sur, Perú

\section{Détection des sources de provenance de l'obsidienne de Pallaucha (Vilcashuaman) par pXRF : Un aperçu des modèles d'échange dans le centre-sud du Pérou au cours de l'Horizon Ancien}

\begin{abstract}
Résumé
Des recherches archéologiques récentes montrent que les hautes terres de la région sud-centrale ont connu d'importants développements socioculturels au cours de l'Horizon Ancien (vers 800-200 av. J.-C.). L'une des raisons de l'importance de cette région était la disponibilité locale de l'obsidienne, un matériau lithique fréquemment échangé. Dans cet article, nous présentons et discutons des résultats d'une étude de détection des sources de provenance de l'obsidienne par spectrométrie de fluorescence $X$ portable (pXRF) sur un échantillon de 26 artefacts provenant du site de Pallaucha, un centre cérémoniel civique de l'Horizon Ancien situé près de Vilcashuaman dans le département d'Ayacucho, au Pérou. L'analyse pXRF démontre que l'obsidienne de Quispisisa était la plus couramment exploitée, malgré l'existence d'autres sources dans les environs de Pallaucha. Nos résultats complètent ceux d'une étude portant sur un large échantillon de l'obsidienne provenant du centre civique et cérémoniel de Campanayuq Rumi, situé à proximité et partiellement contemporain.
\end{abstract}

Mots-clés : pXRF, obsidienne, échange et interaction, Paracas, hautes terres du centre-sud, Pérou

\section{INTRODUCTION}

During the first millennium B.C. or Early Horizon (ca. 800-200 B.C.) (Figure 1), obsidian figured prominently as a prized economic resource that was widely circulated throughout the Peruvian highlands and coast (Burger \& Glascock, 2009; Burger, Lau et al., 2006). As an exotic, obsidian was of importance to both the political and ritual economy of highland centers like Chavín de Huántar and 


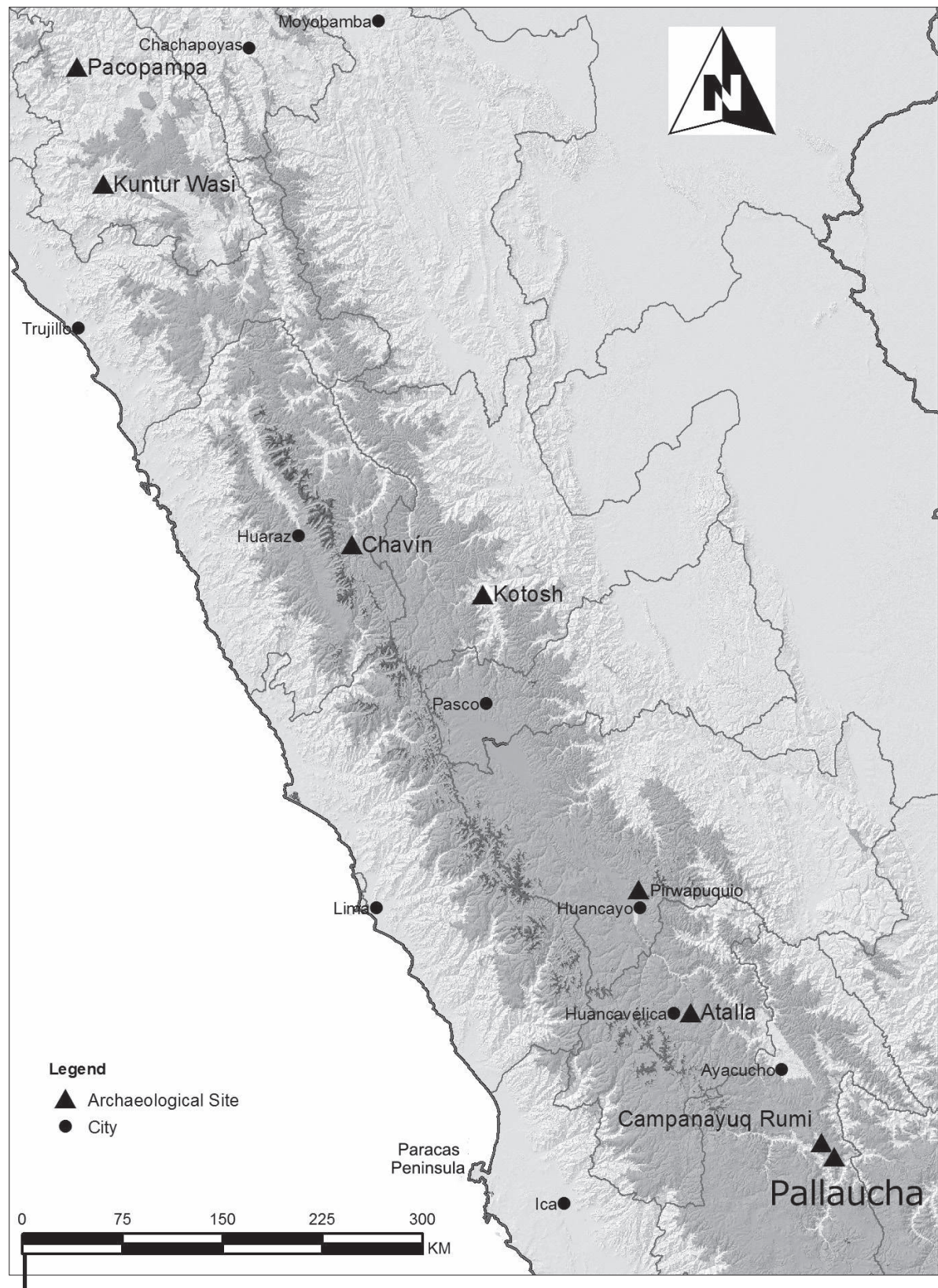

Figure 1 - Map of Peru, showing the locations of Pallaucha and other important Early Horizon sites

Map produced by Bebel Ibarra Asencios 
Campanayuq Rumi (Burger, 1984; Nesbitt, Johnson et al., 2019; Matsumoto et al., 2018; Rick, 2017). Geochemical sourcing studies demonstrate that most of the known obsidian quarries were distributed over a large area of the south-central highlands of Peru (e.g. Glascock et al., 2007; Figure 2). Of these, the most frequently circulated obsidian geochemical type came from the Quispisisa quarry located near the town of Huancasancos in the Department of Ayacucho (Burger \& Glascock, 2000a; Contreras et al., 2012; Tripcevich \& Contreras, 2011; 2013). While Quispisisa obsidian was widely exchanged to Early Horizon ceremonial centers and settlements in the north-central and northern highlands (Burger \& Glascock 2009; Burger, Lau et al., 2006; Matsumoto et al., 2018), its local exploitation in the south-central highlands has been largely understudied (but see Kellett et al., 2013; Matsumoto et al., 2018).

To this point, it is relevant that recent archaeological study in the south-central highlands of Ayacucho has documented multiple large archaeological sites that are positioned near several obsidian sources (e.g. Matsumoto, 2010; Matsumoto \& Cavero, 2009; Mendoza Martínez, 2010; Mendoza Martínez \& Vivanco Pomacanchari, 2019; Nesbitt, Matsumoto et al., 2019) (Figure 2). The presence of these sites demonstrates that the south-central highlands, like its neighbors to the north, was a center of major cultural development during the late second and early first millennia B.C. Among these sites, the best understood is Campanayuq Rumi, a site situated just above the town of Vilcashuaman. Archaeological investigations of Campanayuq Rumi suggest that it emerged as a small village settlement around 1300 B.C. (all dates in this paper are calibrated), before transforming into a large civic-ceremonial center that was occupied between ca. 950 and 450 B.C. (Matsumoto, 2010; Matsumoto \& Cavero, 2009; Matsumoto et al., 2016; Cavero et al., 2019). Various lines of data suggest that Campanayuq Rumi was embedded in long-distance exchange relationships with the north-central highlands and south coast of Peru (Matsumoto, 2010; 2019a; 2019b; Matsumoto \& Cavero, 2009; Nesbitt \& Matsumoto, 2014). The nature of long-distance exchange relationships was further supported by a Portable X-Ray Fluorescence (pXRF) study that established that Campanayuq Rumi obtained obsidian from as many as 7 different obsidian sources during the Campanayuq II Phase (700-400 B.C.). It was at this time that the site was integrated into a panregional network referred to as the "Chavín Interaction Sphere", a "cosmopolitan system of interacting polities spread over a large area of the north and central Peruvian highlands, coastal areas, and tropical forest regions" (Matsumoto et al., 2018: 46). This study further showed that throughout its history, Quispisisa was the most important source, constituting $83.5 \%$ of the obsidian at Campanayuq Rumi (Matsumoto et al., 2018: 54).

However, survey and archaeological research in the Ayacucho region have also documented a series of newly discovered sites with public architecture that also date to the Early Horizon (Mendoza Martínez, 2010; Mendoza Martínez \& Vivanco Pomacanchari, 2019; Nesbitt, Matsumoto et al., 2019). One of these is Pallaucha, a multi-platform complex located just to the southeast of Campanayuq Rumi (Mendoza Martínez, 2017; 2018). Although Pallaucha has a long sequence lasting 
pXRF Sourcing of Obsidian from Pallaucha, Vilcashuaman

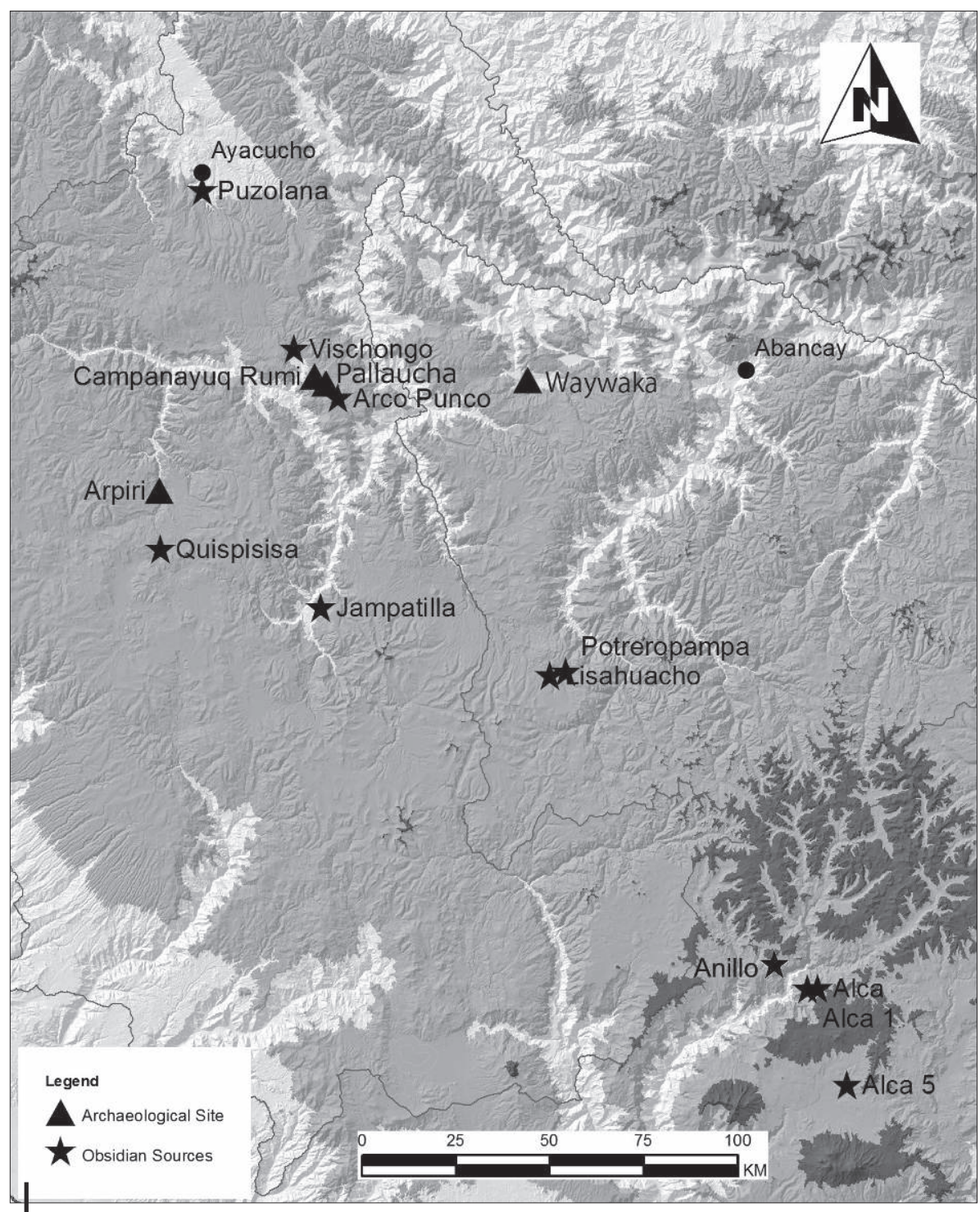

Figure 2 - Map showing obsidian sources and Early Horizon site locations including Pallaucha Map produced by Bebel Ibarra Asencios 
from the Early Horizon until the Late Intermediate Period (ca. AD 1000-1430), its earliest phase is when the site functioned as a village and ceremonial center with public architecture. Although no absolute dates are currently available, the pottery style at Pallaucha indicates that its earliest occupation is contemporary with the Campanayuq II Phase (ca. 700-450 B.C.) at Campanayuq Rumi. Importantly, it also appears that Pallaucha continued to be occupied after Campanayuq Rumi ceased to function as a civic-ceremonial center by ca. 500-450 B.C.

In this paper we report on the results of a pilot pXRF provenience study of 26 obsidian artifacts from Pallaucha. Our objective was to determine if Pallaucha was embedded in similar interaction networks to those of Campanayuq Rumi. Furthermore, we were also interested in determining how procurement patterns changed after the abandonment of Campanayuq Rumi, and the "collapse" of the Chavín Interaction Sphere around ca. 500-450 B.C. Our results suggest that like Campanayuq Rumi, the Quispisisa obsidian source was of long-term importance to the inhabitants of Pallaucha. This result is unsurprising given that the Quispisisa source is located approximately $65 \mathrm{~km}$ to the west of Pallaucha. Yet unlike Campanayuq Rumi, which obtained obsidian from several sources, the patterns from Pallaucha suggest that the site was embedded more strongly in localized interaction networks in the south-central highlands, as well as intermittent connections with the Paracas archaeological culture of the Peruvian south coast (Mendoza Martínez, 2017; see discussion below).

\section{THE ARCHAEOLOGICAL SITE OF PALLAUCHA}

Pallaucha is located $6.3 \mathrm{~km}$ to the southeast of the town of Vilcashuaman and Campanayuq Rumi. At an altitude of approximately $3762 \mathrm{~m}$ asl the site is situated in the high elevation suni grasslands. While Pallaucha has been reported briefly in the archaeological literature (Carrera et al., 2014 [1945-1946]: 32; Pérez et al., 2007: 126), it was only recently that it was subjected to more intensive archaeological investigation directed by Edison Mendoza (Mendoza Martínez, 2017; 2018).

Pallaucha consists of a complex of four terraced platform mounds, distributed over an area of 44 hectares (Mendoza Martínez, 2017: 42). Three of these platforms form a possible alignment oriented along an east-west axis (Figures 3 and 4). In this sense, the spatial organization of Pallaucha differs from nearby civic-ceremonial centers in the region such as Campanayuq Rumi or Arpiri, which exhibit U-shaped layouts that seemingly emulate architectural conventions at Chavín de Huántar (Matsumoto, 2010; Matsumoto \& Cavero, 2009). The platforms that make up Pallaucha consist of natural hills that have been modified by the creation of artificial terraces that are faced with stone retaining walls (see Mendoza 2017 for details) (Figure 5). This technique of modifying the natural landscape was a widespread practice exhibited at many Early Horizon civic-ceremonial centers in the south-central highlands (Matsumoto, 2010; Mendoza Martínez, 2010; Nesbitt, Matsumoto et al., 2019). 
pXRF Sourcing of Obsidian from Pallaucha, Vilcashuaman

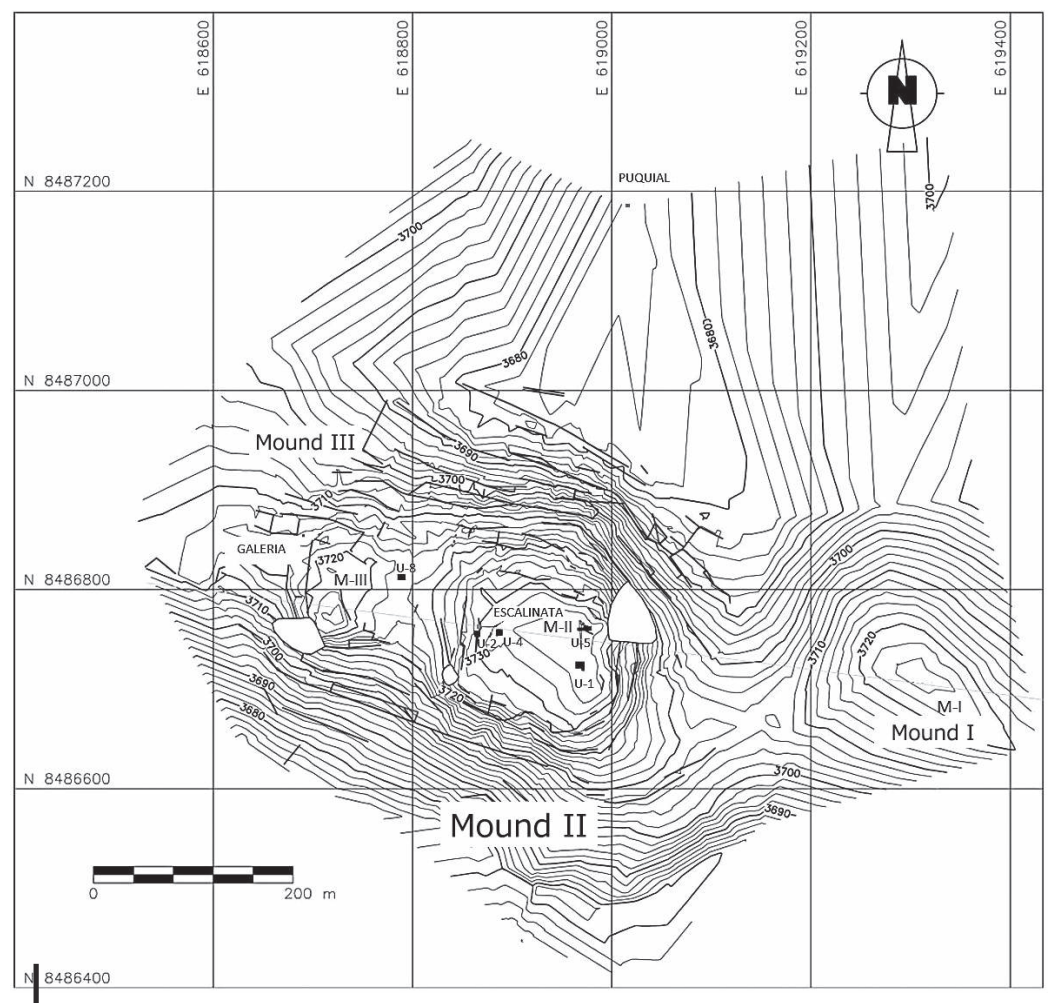

Figure 3 - Map of the site of Pallaucha showing the locations of Mound I-III and the location of excavation units

Map produced by Edison Mendoza Martínez

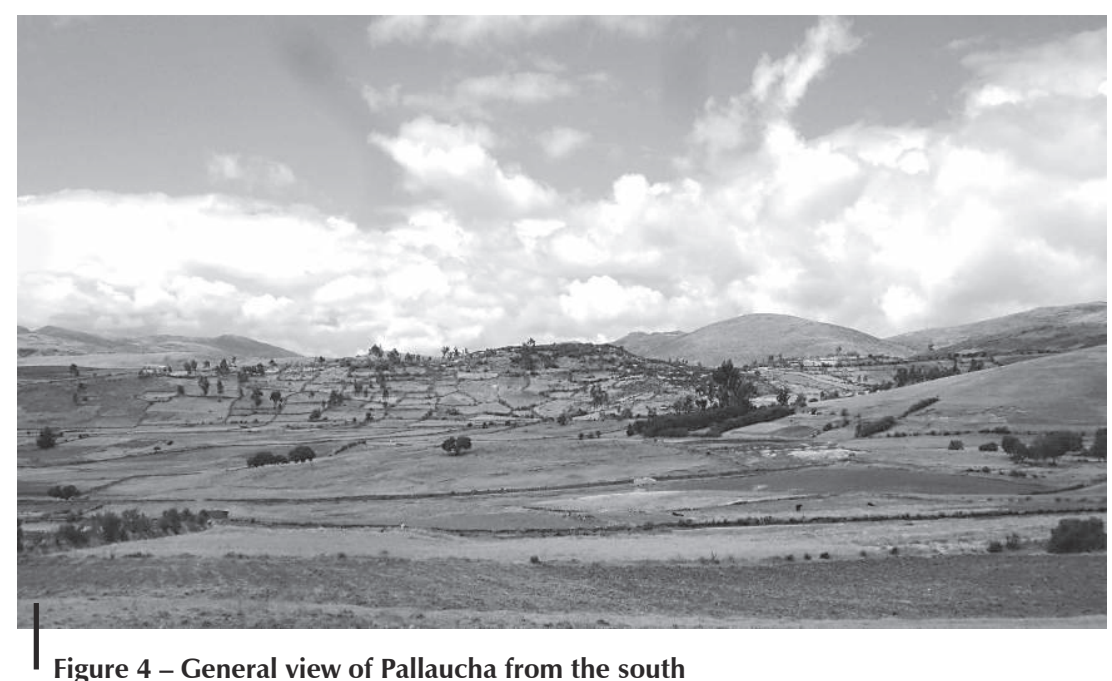

Photo by Edison Mendoza Martínez 


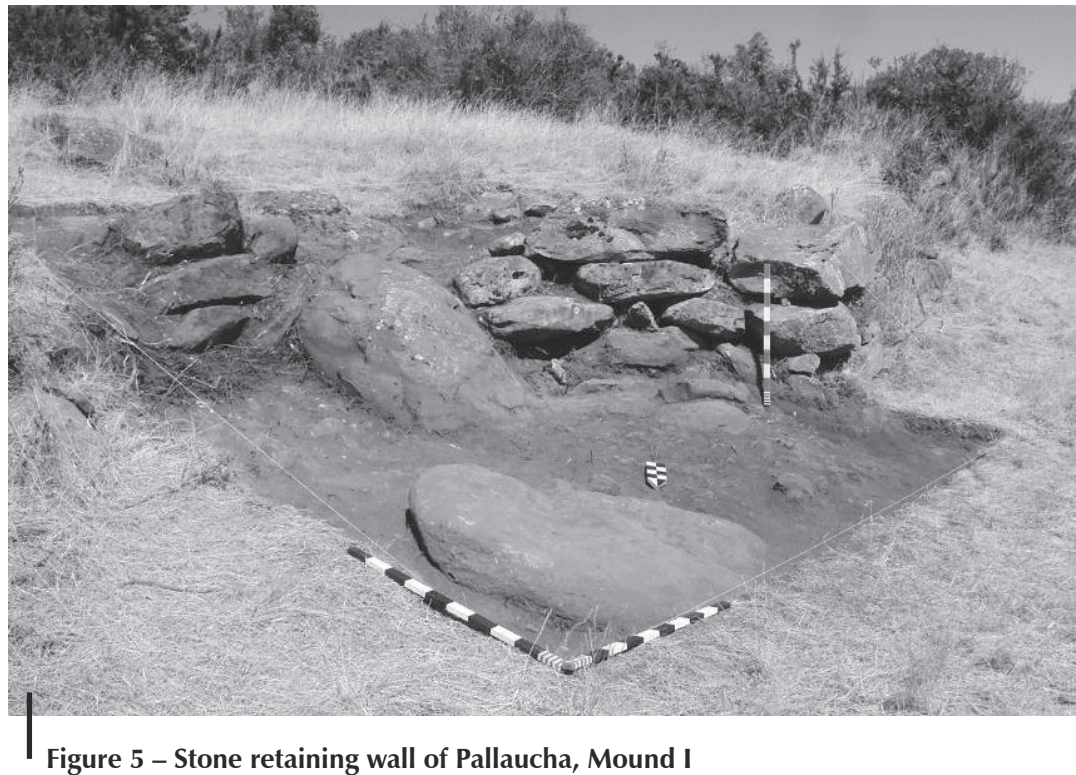

Photo by Edison Mendoza Martínez

Archaeological research at Pallaucha focused primarily on Mound II (Mendoza Martínez, 2017; 2018) (see Figure 3 for the location of excavation units), which consists of two stone-faced terraces that each measure roughly $3 \mathrm{~m}$ in height. Towards the west side of the building there is a central stone staircase that leads to the summit of the mound. On the top of Mound II is a complex of circular buildings that measure between 3 and $5 \mathrm{~m}$ in diameter. The foundations of these structures were built from rounded, locally available fieldstones. It should be noted that the circular buildings at Pallaucha are similar to Early Horizon structures excavated in the domestic sector of Campanayuq Rumi (Matsumoto et al., 2016; Cavero et al., 2019), as well as other contemporary sites in the Ayacucho region (Ochatoma Paravicino, 1998; Pérez Calderón \& Paredes Huarcaya, 2016). Excavation of the circular structures at Pallaucha recovered abundant domestic refuse, suggesting that these buildings functioned as houses and that the site was a small village-sized settlement in the Early Horizon (Mendoza Martínez, 2017; 2018).

The obsidian that is the focus of this article came from Mound II (Table 1), which was where most of the excavations were undertaken (Mendoza Martínez, 2017; 2018). Archaeological investigations of Mound II were aimed at determining the chronology of this building. An $8 \times 12$ m excavation was placed on the summit of Mound II of Pallaucha. This excavation uncovered a superimposed sequence of circular structures that were separated stratigraphically by intentional construction fills (Figure 6). The contexts from which the obsidian was recovered consist of the floors and fills associated with these structures. 


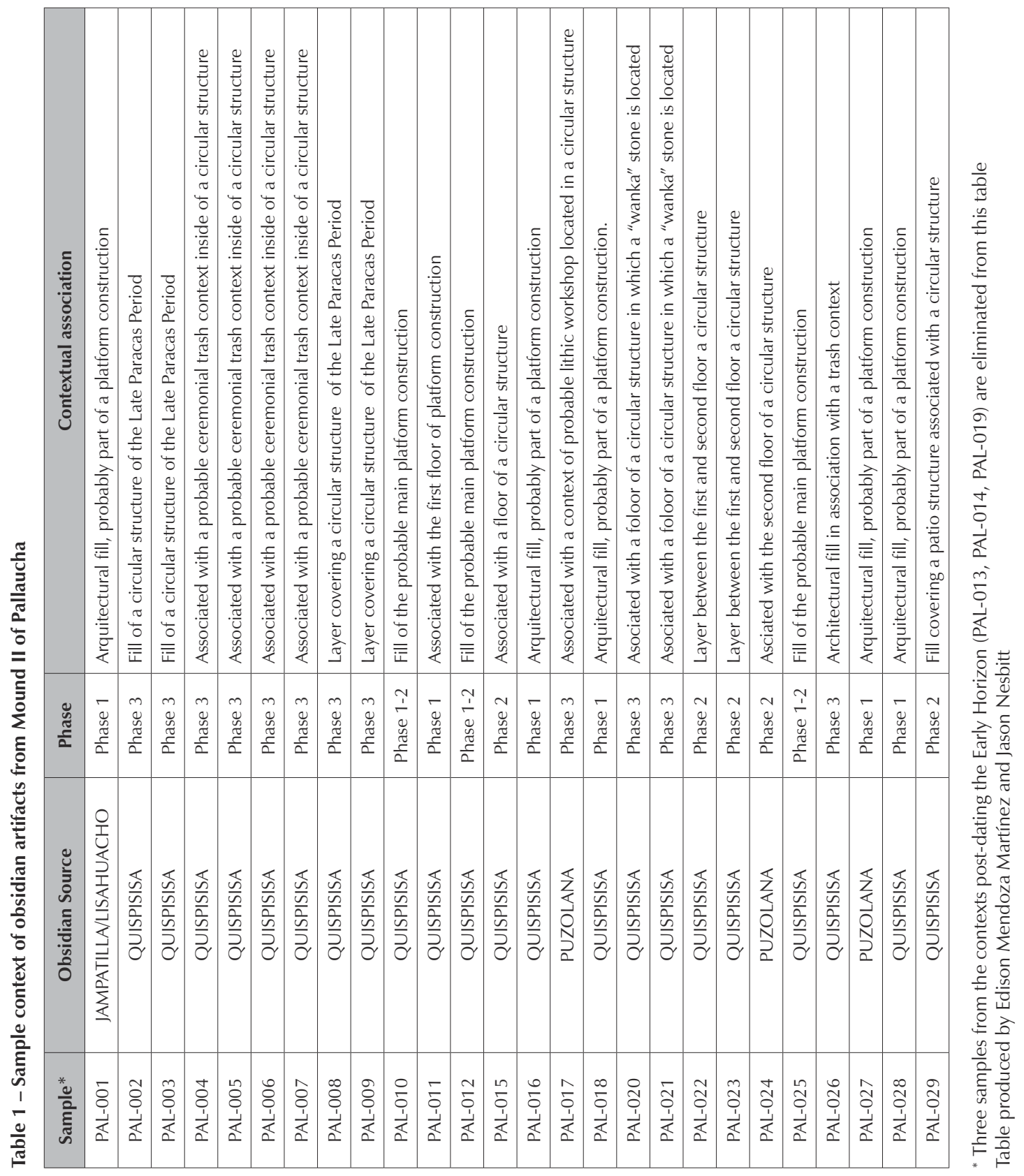




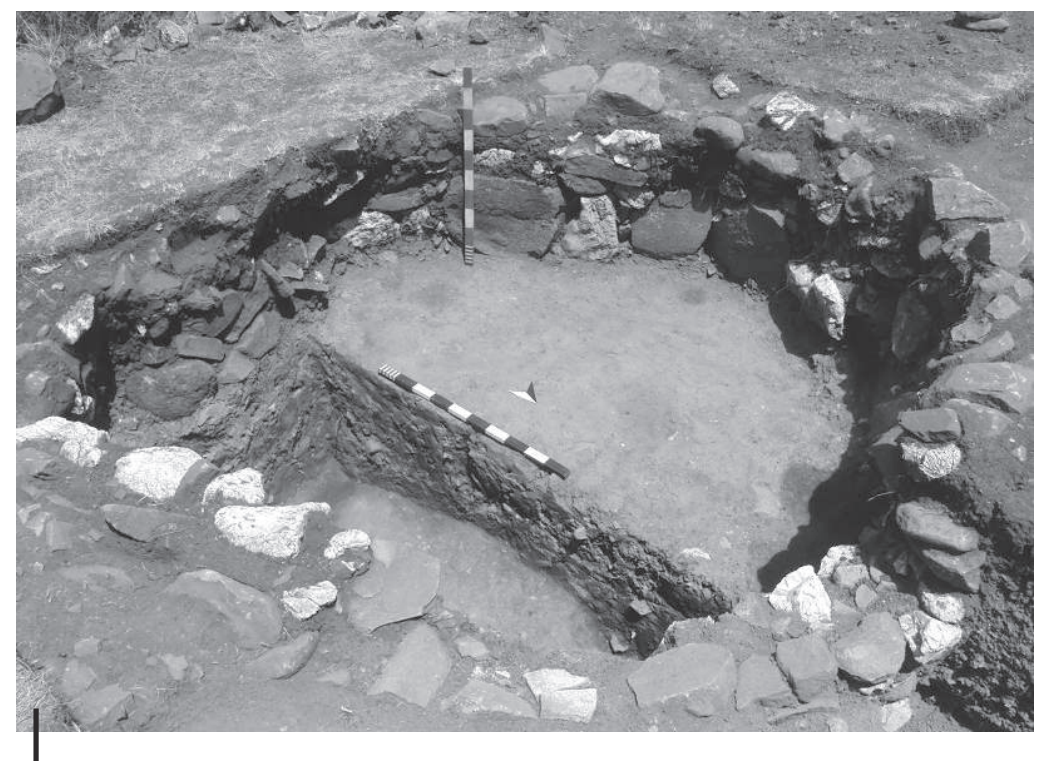

Figure 6 - Early Horizon circular structure at Pallaucha, Mound II

Photo by Edison Mendoza Martínez

\section{THE CHRONOLOGY OF PALLAUCHA}

Mendoza Martínez (2017; 2018) divided Mound II's occupation into three ceramic phases, which span the period between approximately 700 and 250 B.C. At present this chronology is based on associated ceramic materials, which can be tied to the well-established relative and absolute chronology of Campanayuq Rumi (Matsumoto, 2010; Matsumoto \& Cavero, 2009), as well as cross-dated with the Paracas sequence on the south coast of Peru (Unkel et al., 2012) (Figure 7).

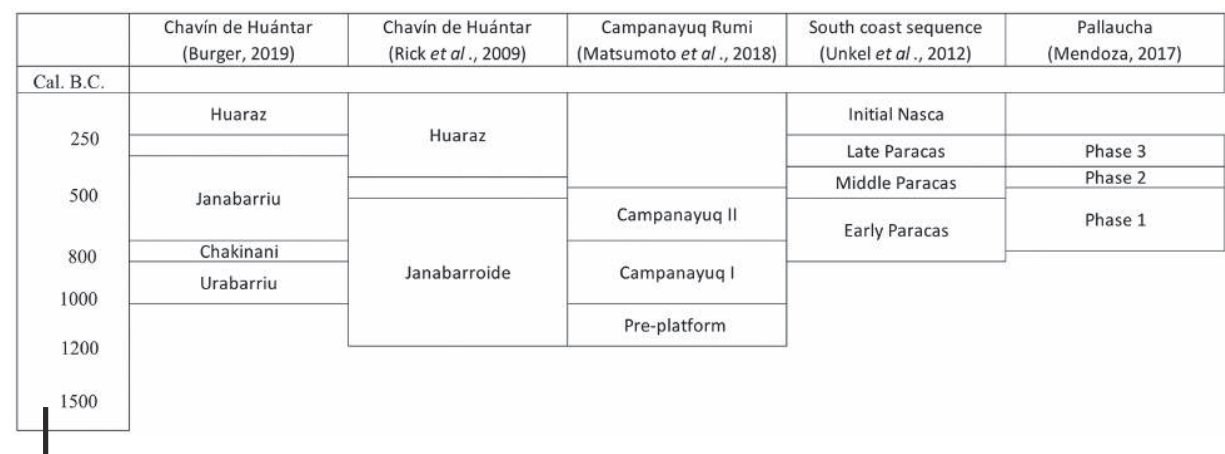

Figure 7 - Chronology of Pallaucha and its relationship to other sites and regions discussed in the text

Figure produced by Yuichi Matsumoto 


\section{1. Phase 1 (ca. 700-450 B.C.)}

The earliest phase of Mound II suggests that this building was founded sometime in the middle part of the Early Horizon (700-450 B.C.). Phase I is defined by the presence of distinctive pottery styles, including vessel fragments with incised circle and dot motifs (Mendoza Martínez, 2017: 106) (Figure 8). This motif is a common element of the Early Horizon contemporary Janabarriu Phase at Chavín de Huántar (Burger, 1984) and is radiocarbon dated between approximately 800/700 and 400 B.C. (c.f. Burger, 2019; Rick et al., 2009). Furthermore, this pottery becomes common at other archaeological sites associated with the Chavín Interaction Sphere at this time (e.g. Burger, 1988).

In addition, there is also a small sample of pottery with negative painting that exhibits brown decoration on a red-colored base. Painted designs include dots and circles, and bands with zig-zag forms (Mendoza Martínez, 2017: 106). These vessels are stylistically identical to pottery from the south coast of Peru, closely matching styles of the Ocucaje 4 and 5 Phases that comprise the early component of the Paracas sequence (Menzel et al., 1964; see also Carmichael, 2019). The presence of Paracas related pottery suggests some interaction with the south coast and south-central highlands of Peru (DeLeonardis, 1997; 2005; Dulanto, 2013; Matsumoto, 2019a; 2019b; Mendoza Martínez, 2017; Young, 2017), a topic that we will return to later in the paper.

While there are no absolute dates available for Pallaucha, the pottery associated with this phase closely resembles the ceramic styles present in the Campanayuq II Phase from Campanayuq Rumi (Matsumoto, 2010; Matsumoto \& Cavero, 2009). In the case of Campanayuq Rumi, the pottery of this phase includes Janabarriurelated pottery, as well as numerous imported vessels from the south coast (Matsumoto, 2019a). Radiocarbon dates place the Campanayuq II Phase in the period between 700 and 450 B.C. (Matsumoto, 2010; Matsumoto \& Cavero, 2009; Matsumoto et al., 2018). This date is also in general agreement with the absolute chronology of the Early Paracas Phase in Palpa (Unkel et al., 2012).

\section{2. Phase 2 (ca. $450-350$ B.C.)}

The second phase of Pallaucha witnesses the disappearance of incised circle and dot pottery and vessels with negative painting. Instead, there is a shift in pottery style to include temporally diagnostic pottery exhibiting red and white post-fire painting and thin, incised lines, as well as stamped incised circles (Mendoza Martínez, 2017: Figure 16A) (Figure 9). Decorative motifs include geometric designs and religious iconography such as eccentric eyes (Mendoza Martínez, 2017: figures 16B-E). During this phase, stylistic features of decorated pottery specimens show a mixture of Middle and Late Paracas, or Ocucaje 5-8 (Menzel et al., 1964). 
Edison Mendoza Martínez, Jason Nesbitt, Yuichi Matsumoto, Yuri Cavero Palomino, Michael D. Glascock
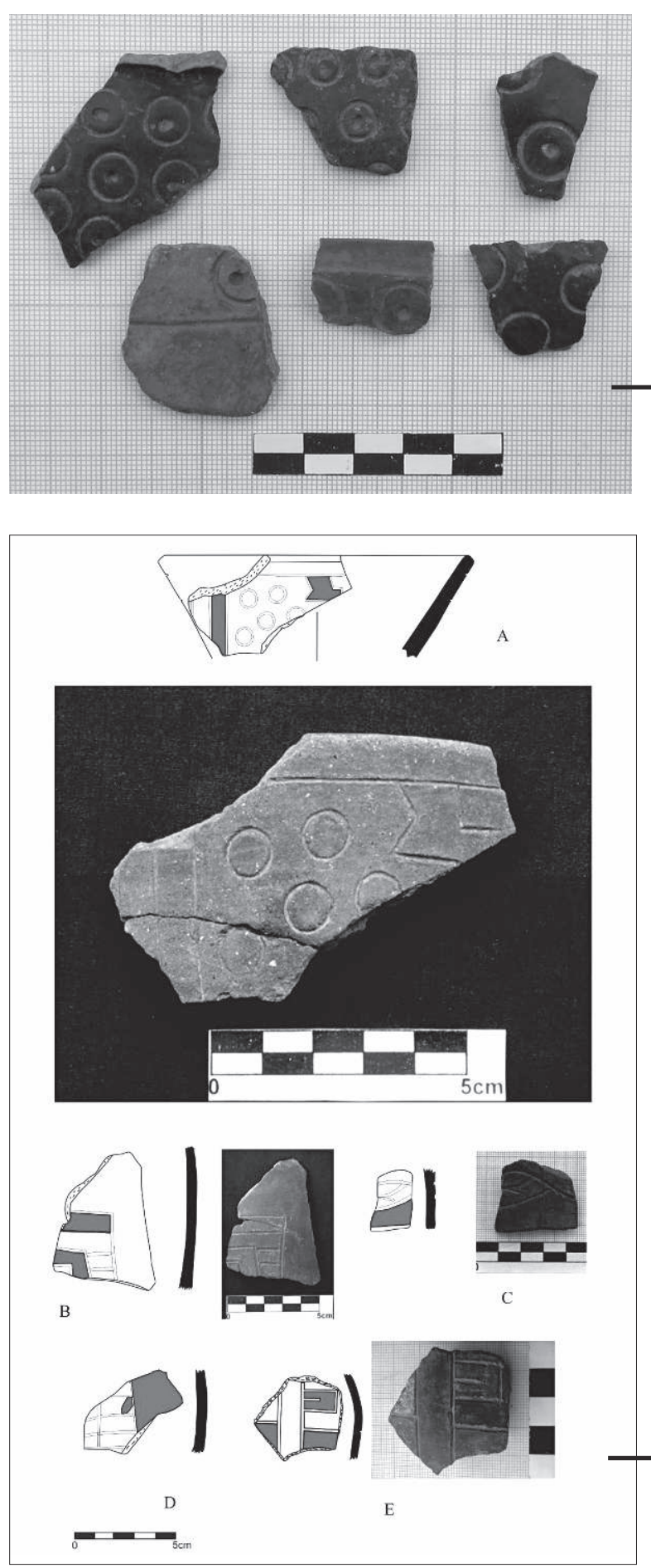

Figure 8 - Phase 1 pottery from Pallaucha

Photo by Edison Mendoza Martínez
Figure 9 - Phase 2 pottery from Pallaucha

Photo by Edison Mendoza Martínez 


\section{3. Phase 3 (ca. $350-250$ B.C.)}

During Phase 3 there is another change in pottery styles at Pallaucha, particularly with respect to the Paracas-related materials. Designs included interlocking bands and incision and cane stamped circles. Mendoza Martínez (2017) also describes sherds that resemble motifs exhibited in the Ocucaje 8 Phase (e.g. Menzel et al., 1964) (Figure 10), which has recently been radiocarbon dated to ca. 380-260 B.C. (Unkel et al., 2012: 2299).

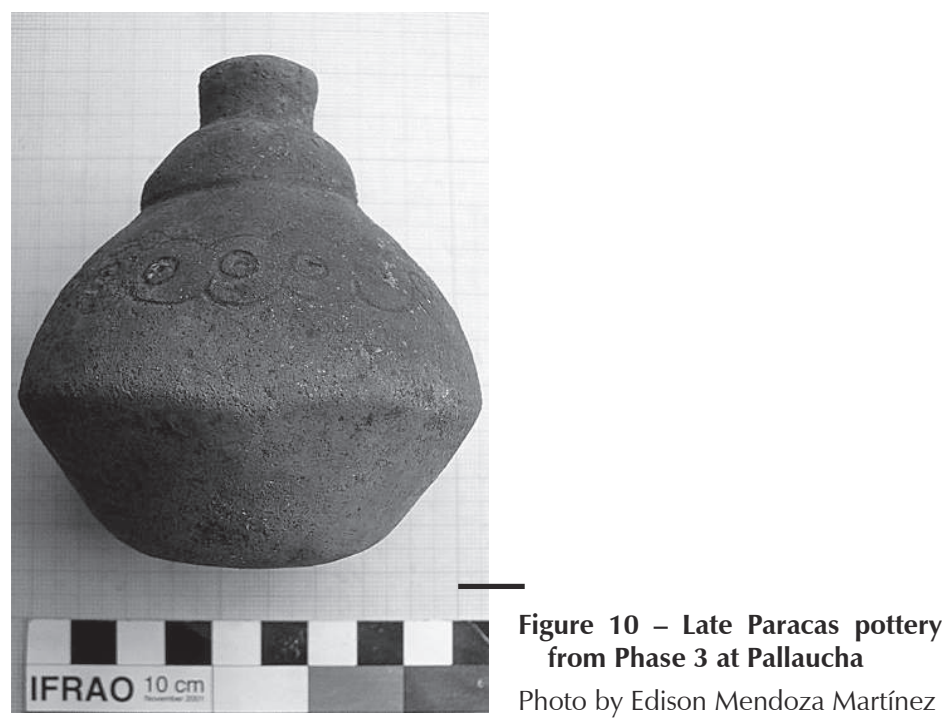

\section{4. Summary}

The relative chronological sequence indicates that Pallaucha was occupied throughout the middle and later parts of the Early Horizon, or between ca. 700 and 250 B.C. Although Phase 1 corresponds to the Campanayuq II Phase and can be tied to Early Paracas (ca. 700-450 B.C.) (Matsumoto, 2010; Matsumoto \& Cavero, 2009), Phases 2 and 3 correspond to the time of abandonment at Campanayuq Rumi and are thus difficult to relate to the Campanayuq sequence. The general stylistic traits show an affiliation to Late Paracas in the south coast and the Chupas type in the Ayacucho basin (Lumbreras, 1974; Ochatoma Paravicino, 1998) and can be defined as Janabarriu-related pottery (Burger, 1992: 213).

The earliest phase (Phase 1) of Pallaucha is significant because it is contemporary with the nearby, larger, civic-ceremonial center of Campanayuq Rumi. However, unlike Campanayuq Rumi, which was largely abandoned by ca. 500- 400 B.C., Pallaucha continued to function as an Early Horizon settlement until as late as 250 B.C. Therefore, using the radiocarbon dates and ceramic sequences from 
Campanayuq Rumi and south coast (Unkel et al., 2012; Matsumoto, 2010; Matsumoto \& Cavero, 2009), we tentatively estimate the dates of each phase as follows; Phase 1: ca. 700-450 B.C.; Phase 2: ca. 450-350 B.C.; Phase 3: ca. 350250 B.C.

\section{3. pXRF ANALYSIS OF OBSIDIAN FROM PALLAUCHA}

Obsidian was a common artifact material at Pallaucha and constituted the vast majority of the lithic assemblage. Like other south-central lithic assemblages of the Early Horizon, the obsidian tools were primarily characterized by flake tools (Nesbitt, Johnson et al., 2019), though scrapers and bifaces were also recovered. A total of 26 obsidian flakes from Pallaucha were analyzed by pXRF for this study. This constitutes approximately $2.4 \%$ of the overall obsidian assemblage $(n=1091)$. The analysis was undertaken in August of 2014 at the UNSAAC-Yale International Center for the Study of Machu Picchu and Inca Culture in Cuzco, Peru, as part of a larger study of diachronic patterns of obsidian utilization during the Initial Period and Early Horizon in the south-central highlands (Matsumoto et al., 2018). Obsidian samples were selected from Phase $1(n=9)$, Phase $2(n=5)$, and Phase $3(n=12)$ contexts. While this sample is small, it does provide insight into important trends in obsidian procurement patterns during the Early Horizon. Furthermore, this data is useful for preliminary comparison with the nearby site of Campanayuq Rumi.

Obsidian artifacts from Pallaucha were analyzed using a Bruker Tracer Series IIISD pXRF spectrometer. Measurements with the pXRF were undertaken with an operating voltage of $40 \mathrm{keV}$ and current of 30 microamps. Measurement times were 60 seconds per sample. The XRF was calibrated for analysis of obsidian by using the Missouri Research Reactor (MURR) suite of 40 obsidian source specimens and their associated concentration data (Glascock \& Ferguson, 2012). The elements for which the concentrations could be determined in obsidian include Mn, Fe, Zn, $\mathrm{Ga}, \mathrm{Rb}, \mathrm{Sr}, \mathrm{Y}, \mathrm{Zr}, \mathrm{Nb}$, and Th.

\section{RESULTS}

The results of the obsidian study are presented in Figure 11 and Table 2. Obsidian came from three, or possibly four, geochemical sources: Quispisisa, Puzolana, and either Jampatilla or Lisahuacho (discussed below). However, the Quispisisa source dominates, comprising nearly 85 percent of the overall assemblage $(n=22)$. This result closely matches the proportion of obsidian acquired from Quispisisa for all chronological phases at Campanayuq Rumi (Matsumoto et al., 2018).

Though the sample is small $(n=9)$, it is during Phase 1 that Pallaucha exhibits the most diversity in terms of exploited sources. Seven of the obsidian flakes can be sourced to the Quispisisa source. Located near the towns of Sacsamarca and Huancasancos in the Department of Ayacucho, Quispisisa was a large quarry known for high quality obsidian (Burger \& Glascock, 2000a; 2002; Contreras et al., 2012; 
pXRF Sourcing of Obsidian from Pallaucha, Vilcashuaman

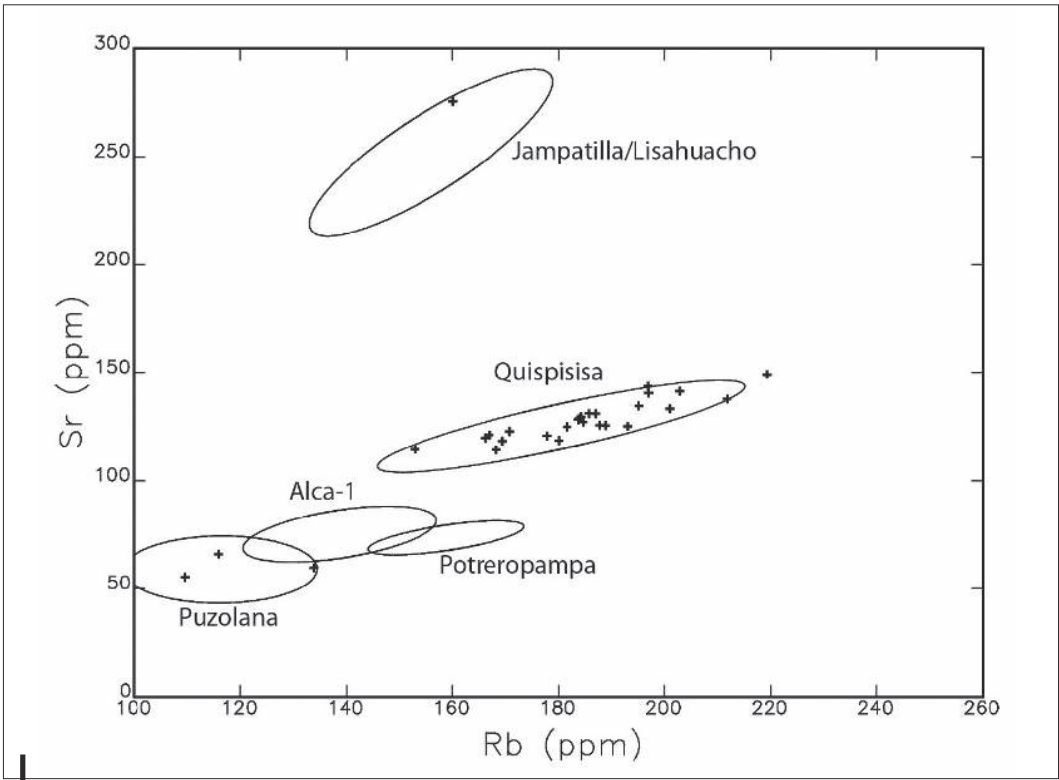

Figure 11 - Bivariate scatterplot of Rubidium versus Strontium for obsidian artifacts from Pallaucha compared to sources in Peru. Sources are displayed as $\mathbf{9 0 \%}$ confidence ellipses

Figure produced by Michael D. Glascock

Table 2 - Obsidian counts from Pallaucha by phase

\begin{tabular}{|c|c|c|c|}
\hline \multicolumn{4}{|c|}{ Obsidian Counts Overall $(n=26)$ : Phases Combined } \\
\hline Quispisisa & \multicolumn{3}{|c|}{$22(84.62 \%)$} \\
\hline Jampatilla/Lisahuacho & \multicolumn{3}{|c|}{$1 \quad(3.85 \%)$} \\
\hline Puzolana & \multicolumn{3}{|c|}{$3(11.54 \%)$} \\
\hline Total & \multicolumn{3}{|c|}{$26 \quad(100 \%)$} \\
\hline \multicolumn{4}{|c|}{ Obsidian Counts Overall by Phase $(n=26)$} \\
\hline & Phase 1 & Phase 2 & Phase 3 \\
\hline Quispisisa & $7(77.78 \%)$ & $4(80.00 \%)$ & $11(91.67 \%)$ \\
\hline Jampatilla/Lisahuacho & $1(11.11 \%)$ & 0 & $0 \quad(3.51 \%)$ \\
\hline Puzolana & $1(11.11 \%)$ & $1(20.00 \%)$ & $1 \quad(8.33 \%)$ \\
\hline Total & 9 & 5 & 12 \\
\hline
\end{tabular}

Table produced by Jason Nesbitt 
Tripcevich \& Contreras, 2011; 2013). Survey of the Quispisisa source documented numerous large quarrying pits, which attest to the intensity of ancient exploitation of this locality (Tripcevich \& Contreras, 2011; 2013).

A single flake pertains to the Puzolana geochemical source. While originally located in the region just to the south of the city of Ayacucho (Burger \& Glascock, 2000b), recent research indicates that Puzolana was a more diffuse source that was distributed over a wide area (Giesso et al., 2020), including localities in Vischongo and Vilcashuaman (Matsumoto et al., 2018). Furthermore, there is another locality, known as Arco Punco, that is located just over $2 \mathrm{~km}$ to the south/ southeast of Pallaucha that has obsidian that geochemically matches Puzolana (Matsumoto et al., 2018: 55). Arco Punco is a high hill with natural deposits of obsidian nodules within an ash/tephra matrix. Nodules from these deposits measure up to $7 \mathrm{~cm}$ in diameter, which is of adequate size for manufacturing flake tools. Given its proximity to Pallaucha, we hypothesize that the Puzolana obsidian was probably obtained from Arco Punco, rather than the immediate vicinity of Ayacucho which is roughly $65 \mathrm{~km}$ to the north of Pallaucha.

Finally, one flake pertains to either the Lisahuacho or Jampatilla source. Unfortunately, these two sources cannot be distinguished utilizing a pXRF (see also Matsumoto et al., 2018: 55 for a discussion of this issue). Lisahuacho is located near Chalhuanca in Apurimac (Burger, Fajardo et al., 2006) and is approximately $95 \mathrm{~km}$ to the south of Pallaucha, while Jampatilla is situated $57 \mathrm{~km}$ to the south (Burger, Schreiber et al., 1998).

In Phase $2(n=5)$ Quispisisa continues to be the most common source $(n=4)$ with one sample from Puzolana. This pattern continues in Phase $3(n=12)$ in which eleven obsidian artifacts come from Quispisisa, while a single flake is from Puzolana.

\section{OBSIDIAN PROCUREMENT AT PALLAUCHA IN A WIDER GEOGRAPHIC CONTEXT}

The pXRF analysis presented above illustrates that throughout its history, the inhabitants of Pallaucha relied on a limited number of obsidian sources. In overall terms, the most common source area for obsidian at Pallaucha was the Quispisisa source, which constituted nearly 85 percent of the assemblage $(n=22)$. This result demonstrates the long-term importance of Quispisisa obsidian throughout Pallaucha's history. Quispisisa is roughly $65 \mathrm{~km}$ to the west of Pallaucha. As noted earlier, this quarry was one of the most important sources of obsidian in highland Peru during the Early Horizon. A round-trip journey from Pallaucha to Quispisisa would consist of 8-12 days travel time (see Matsumoto et al., 2018: 58 for a discussion).

The results are also instructive when compared to a study of a much larger sample of obsidian ( $n=370)$ from Campanayuq Rumi. In the case of Campanayuq Rumi, obsidian from the Quispisisa source comprises just under 84 percent of the sample 
(Matsumoto et al., 2018). Therefore, Pallaucha, like Campanayuq Rumi, was closely tied to the Quispisisa area. Yet there are apparent differences between obsidian consumption at Pallaucha and Campanayuq Rumi. For instance, during the Campanayuq Rumi II Phase, which is contemporary with Phase I at Pallaucha, Campanayuq Rumi was obtaining small amounts of obsidian from far more distant regions, including the Alca obsidian source, which is roughly $200 \mathrm{~km}$ to the west (Burger, Asaro et al., 1998; Rademaker et al., 2013). Additionally, a total of 6, and perhaps 7, sources were exploited at Campanayuq Rumi (Matsumoto et al., 2018). Matsumoto and colleagues argued that this diversity of sources indicated that Campanayuq Rumi was a type of cosmopolitan center that was a major community for the circulation of obsidian within the Chavín Interaction Sphere. It may be that in the contemporary Phase 1 that Pallaucha was involved in more localized obsidian exchange networks, given the limited number of sources present. Similar patterns of more restricted exchange in obsidian have also been noted elsewhere in the south-central highlands (Kellett et al., 2013). The pattern throughout Pallaucha's history seems to focus on procurement from the relatively nearby Quispisisa source. In this sense, Pallaucha follows a pattern akin to the Middle Horizon centers of Huari and Conchopata, as well as Inca settlements in the Vilcashuaman region, in which obsidian was procured virtually exclusively from the Quispisisa obsidian source (Burger et al., 2016; Hu \& Shackley, 2018).

In the case of Pallaucha, the low proportion of Puzolana obsidian is somewhat surprising given that Puzolana obsidian was available from multiple sources within very short distances from the site. As noted earlier, the nearby quarry at Arco Punco has nodules up to $7 \mathrm{~cm}$ in diameter that are large enough for working into the types of flake tools and points that are found at Pallaucha. That said, and as observed by Burger and Glascock (2000b: 293), the people of the south-central highlands generally preferred Quispisisa obsidian because of the much larger, high-quality nodules. The presence of Quispisisa suggest that throughout its history, Pallaucha had reliable ties with this area and source.

In this context, it is important to emphasize that Pallaucha continued to function after the abandonment of Campanayuq Rumi, which demonstrates that Pallaucha survived the collapse of the Chavín Interaction Sphere around ca. 500-450 B.C. (Burger, 2019; Nesbitt et al., 2020; Rick et al., 2009). The presence of Paracas pottery at Pallaucha demonstrates that even after the collapse of this pan-regional network, interregional ties between the south coast and south-central highlands remained active. This observation is interesting considering that their ties were initially consolidated through the emergence of the Chavín Interaction Sphere through the expansion of a shared religious ideology and formation of religious network (Burger, 1988; 2008; Matsumoto, 2010; 2019b; Matsumoto et al., 2018). The obsidian provenience data from south coast cultures indicate that the importance of Quispisisa obsidian continued into Late Paracas times and even afterwards (Burger, 2007; DeLeonardis \& Glascock, 2013; Van Gijseghem, 2006; Vaughn \& Glascock, 2005). This pattern of sustained interaction between the south coast and the south-central highlands contrasts with the case of the north-central 
highlands where the disintegration of the Chavín Interaction Sphere resulted in a substantial reduction in the obsidian trade (Burger, Lau et al., 2006). In other words, it appears that after ca. 500-450 B.C, the south-central highlands become largely cut off from the north-central and northern Peruvian highlands. Applying arguments concerning the Chavín Phenomenon and expansion of the "Chavín cult" (Burger, 1988; 1992; 1993), Matsumoto argues that the Early Paracas cultures of the south coast were connected by pilgrimage to Campanayuq Rumi's identity as a branch shrine of Chavín de Huántar (Matsumoto, 2010; 2019a: 57; 2019b). In accordance with the disappearance of the centripetal force of Campanayuq Rumi as a node of interregional interaction, other local centers such as Pallaucha could have emerged or transformed into independent agents and their relationships were not based on the foreign religion related to Chavín. Instead, this change might be related to the emergence of Late Paracas societies along the south coast that developed regional centers with unprecedented population densities (e.g. Bachir Baccha \& Llanos, 2015; DeLeonardis, 1997; Massey, 1986; 1991; Reindel et al., 2015; Silverman, 1994; 1996; Soßna, 2015). This change can be regarded as the apex of Paracas culture, though the impact of highland societies such as those that inhabited Pallaucha remains to be explored (Young, 2017). However, the provenience data from Pallaucha suggests that the trade of Quispisisa obsidian continues to be a key factor to consider this issue.

\section{Acknowledgements}

The pXRF analysis of the Pallaucha samples presented in this article was carried out as part of the archaeometry workshop undertaken at the Casa Concha, Cuzco with the financial support of Yale University as part of the ongoing educational exchange program between the archaeology programs of Yale and the Universidad Nacional de San Antonio Abad de Cuzco (UNSAAC). Costs for analysis of the artifacts were also covered by a National Science Foundation grant (1415403) to the Archaeometry Lab at the University of Missouri Research Reactor and the Roger Thayer Stone Center for Latin American Studies at Tulane University. Special thanks to Peter Kaulicke, Jahl Dulanto, José Ochatoma and Martha Cabrera for their support and advice concerning the investigations at Pallaucha carried out by Edison Mendoza. Our deepest appreciation goes to Richard Burger, Bebel Ibarra, Rachel Johnson, Rachel Witt, and two anonymous reviewers for providing us with valuable suggestions that improved the quality of this manuscript. We also thank Kristina Douglass for kindly translating our abstract into French.

\section{References cited}

BACHIR BACHA, A. \& LLANOS, O. D., 2015 - ¿Hacia un urbanismo paracas en Ánimas Altas/Ánimas Bajas (Valle de Ica)? Boletín de Arqueología PUCP, 17: 169-204.

BURGER, R. L., 1984 - The Prehistoric Occupation of Chavín de Huántar, Peru, xv + 403 pp.; Berkeley: University of California Press. 
BURGER, R. L., 1988 - Unity and heterogeneity within the Chavín horizon. In: Peruvian Prehistory: An overview of pre-Inca and Inca society (R. W. Keatinge, ed.): 99-144; Cambridge: Cambridge University Press.

BURGER, R. L., 1992 - Chavín and the Origins of Andean Civilization, 248 pp.; Londres: Thames and Hudson.

BURGER, R. L., 1993 - The Chavín Horizon: Stylistic Chimera or Socioeconomic Metamorphosis? In: Latin American Horizons (D. Rice, ed.): 41-82; Washington, D. C.: Dumbarton Oaks Research Library and Collection.

BURGER, R. L., 2007 - Late Paracas Obsidian Tools from Animas Altas. Andean Past, 8: 477-492.

BURGER, R. L., 2008 - Chavín de Huántar and Its Sphere of Influence. In: Handbook of South American Archaeology (H. Silverman \& W. H. Isbell, eds.): 681-703; Nueva York: Springer.

BURGER, R. L., 2019 - Understanding the Socioeconomic Trajectory of Chavín de Huántar: A New Radiocarbon Sequence and Its Wider Implications. Latin American Antiquity, 30 (2): 373-392.

BURGER, R. L., ASARO, F., TRAWICK, P. \& STROSS, F., 1998 - The Alca Obsidian Source: The Origin of Raw Material for Cuzco Type Obsidian Artifacts. Andean Past, 5: 182-202.

BURGER, R. L., BENCIC, C. M. \& GLASCOCK, M. D., 2016 - Obsidian Procurement and Cosmopolitanism at the Middle Horizon Settlement of Conchopata, Peru. Andean Past, 12: 21-44.

BURGER, R. L. \& GLASCOCK, M. D., 2000a - Locating the Quispisisa Obsidian Source in the Department of Ayacucho, Peru. Latin American Antiquity, 11 (3): 258-268.

BURGER, R. L. \& GLASCOCK, M. D., 2000b - The Puzolana Obsidian Source: Locating the Geologic Source of Ayacucho Type Obsidian. Andean Past, 6: 289-307.

BURGER, R. L. \& GLASCOCK, M. D., 2002 - Tracking the Source of Quispisisa Type Obsidian from Huancavelica to Ayacucho. In: Andean Archaeology. Vol. 1: Variations in Sociopolitical Organization (W. H. Isbell \& H. Silverman, eds.): 341-368; Nueva York: Kluwer Academic/Plenum Publishers.

BURGER, R. L. \& GLASCOCK, M. D., 2009 - Intercambio prehistórico de obsidiana a larga distancia en el Norte Peruano. Revista del Museo de Arqueología, Antropología e Historia, 11: 17-50.

BURGER, R. L., FAJARDO RIOS, F. A. \& GLASCOCK, M. D., 2006 - Potreropampa and Lisahuacho obsidian sources: geological origins of Andahuaylas A and B type obsidians in the Province of Aymares, Department of Apurimac, Peru. Nawpa Pacha: Journal of Andean Archaeology, 28 (1): 109-127.

BURGER, R. L., LAU, G. F., PONTE, V. M. \& GLASCOCK, M. D., 2006 - The History of Prehispanic Obsidian Procurement in Highland Ancash. In: La complejidad social en la sierra de Ancash: ensayos sobre paisaje, economía y continuidades culturales. Trabajos de la primera y segunda Mesa Redonda de Arqueología de la Sierra de Ancash (A. Herrera, C. Orsini \& K. Lane, eds.): 103-120; Milán, Lima: Civiche Raccolte d'Arte Aplicada del Castello Sforzesco, PUNKU Centro de Investigación Andina.

BURGER, R. L., SCHREIBER, K., GLASCOCK, M. D. \& CCENCHO, J., 1998 - The Jampatilla Obsidian Source: Identifying the Geological Source of Pampas Type Obsidian Artifacts from Southern Peru. Andean Past, 5: 225-229. 
CARMICHAEL, P. H., 2019 - Stages, Periods, Epochs, and Phases in Paracas and Nasca Chronology: Another Look at John Rowe's Ica Valley Master Sequence. Nawpa Pacha: Journal of Andean Archaeology, 39 (2): 145-179.

CARRERA, P., FARFÁN, G. \& GONZÁLEZ, M., 2014 [1945-1946] - Expedición arqueológica a la cuenca del río Pampas, 45 pp.; Lima: Museo Nacional de Antropología y Arqueología. [Republished in Revista Conchopata, 4: 11-56.]

CAVERO, Y., MATSUMOTO, Y. \& NESBITT, J., 2019 - Excavaciones arqueológicas Campanayuq Rumi, Vilcashuamán, Ayacucho: tercera temporada de campo (2016). In: Actas del IV Congreso Nacional de Arqueología (Volumen II): 45-54; Lima: Ministerio de Cultura.

CONTRERAS, D. A., TRIPCEVICH, N. \& CAVERO PALOMINO, Y. I., 2012 - Investigaciones en la fuente de la obsidiana tipo Quispisisa, Huancasancos-Ayacucho. Investigaciones Sociales, 16 (28): 185-195.

DeLEONARDIS, L., 1997 - Paracas Settlement in Callango, Lower Ica Valley, First Millennium BC Peru; Washington, D. C.: Catholic University of America. Tesis de doctorado.

DeLEONARDIS, L., 2005 - Early Paracas Cultural Contexts: New Evidence from Callango. Andean Past, 7: 27-55.

DeLEONARDIS, L. \& GLASCOCK, M. D., 2013 - From Queshqa to Callango: A Paracas Obsidian Assemblage from the Lower Ica Valley, Peru. Nawpa Pacha: Journal of Andean Archaeology, 33 (2): 163-192.

DULANTO, J., 2013 - Puerto Nuevo: Redes de intercambio a larga distancia durante la primera mitad del primer milenio Andes de nuestra era. Boletín de Arqueología PUCP, 17: 103-132.

GIESSO, M., NAMI, H. G., YATACO CAPCHA, J. J., GLASCOCK, M. D. \& MACDONALD, B. L., 2020 - XRF Obsidian Analysis from Ayacucho Basin in Huamanga Province, South-eastern Peru. Archaeometry, 62 (2): 215-231.

GLASCOCK, M. D. \& FERGUSON, J. R., 2012 - Report on the Analysis of Obsidian Source Samples by Multiple Analytical Methods. Prepared for Bruker Elemental. Report on file, University of Missouri-Columbia.

GLASCOCK, M. D., SPEAKMAN, R. J. \& BURGER, R. L., 2007 - Sources of Archaeological Obsidian in Peru: Descriptions and Geochemistry. In: Archaeological Chemistry: Analytical Techniques and Archaeological Interpretation (M. D. Glascock, R. J. Speakman \& R. S. Popelka-Filcoff, eds.): 522-552; Washington, D. C.: American Chemical Society.

HU, D. \& SHACKLEY, M. S., 2018 - ED-XRF Analysis of Obsidian Artifacts from Yanawilka, a Settlement of Transplanted Laborers (mitmaqkuna), and Implications for Inca Imperialism. Journal of Archaeological Science: Reports, 18: 213-221.

KELLETT, L. C., GOLITKO, M. \& BAUER, B. S., 2013 - A provenance study of archaeological obsidian from the Andahuaylas region of southern Peru. Journal of Archaeological Science, 40 (4): 1890-1902.

LUMBRERAS, L. G., 1974 - Las fundaciones de Huamanga: Hacia una prehistoria de Ayacucho, 238 pp.; Lima: Club Huamanga.

MASSEY, S. A., 1986 - Sociopolitical Change in the Upper Ica Valley, B.C. 400 to 400 A.D.: Regional States on the South Coast of Peru (Paracas, Nasca, Topara); Los Ángeles: University of California. Tesis de doctorado.

MASSEY, S. A., 1991 - Social and Political Leadership in the Lower Ica Valley: Ocucaje Phases 8 and 9. In: Paracas Art and Architecture: Object and Context in South Coastal Peru (A. Paul, ed.): 315-348; lowa City: University of lowa Press. 
MATSUMOTO, Y., 2010 - The Prehistoric Ceremonial Center of Campanayuq Rumi: Interregional Interactions in the South-Central Highlands of Peru; New Haven, Connecticut: Yale University. Department of Anthropology. Tesis de doctorado.

MATSUMOTO, Y., 2019a - Paracas en la Sierra: Interacción temprana entre la Sierra Centro Sur y Costa Sur. Peruvian Archaeology, 3: 33-64.

MATSUMOTO, Y., 2019b - South of Chavín: Initial Period and Early Horizon Interregional Interactions between the Central Highlands and South Coast. In: Perspectives on Early Andean Civilization in Peru: Interaction, Authority, and Socioeconomic Organization during the First and Second Millennium BC (R. L. Burger, L. C. Salazar \& Y. Seki, eds.): 173-188; New Haven, Connecticut: Yale University Press.

MATSUMOTO, Y. \& CAVERO, Y. I., 2009 - Una aproximación cronológica del centro ceremonial de Campanayuq Rumi, Ayacucho. Boletín de Arqueología PUCP, 13: 323-346.

MATSUMOTO, Y., NESBITT, J., CAVERO PALOMINO, Y. \& MENDOZA MARTÍNEZ, E., 2016 - Actividades rituales en áreas circundantes al centro ceremonial de Campanayuq Rumi, Vilcashuamán, Ayacucho. In: Actas del I Congreso Nacional de Arqueología (Volumen II): 99-104; Lima: Ministerio de Cultura.

MATSUMOTO, Y., NESBITT, J., GLASCOCK, M. D., CAVERO PALOMINO, Y. I. \& BURGER, R. L., 2018 - Interregional Obsidian Exchange during the Late Initial Period and Early Horizon: New Perspectives from Campanayuq Rumi, Peru. Latin American Antiquity, 29 (1): 44-63.

MENDOZA MARTÍNEZ, E., 2010 - Investigaciones arqueológicas en la margen izquierda de los ríos Yanamayu y Pampas, Vilcashuamán, Ayacucho. Revista Pacha Runa, 1: 123-162.

MENDOZA MARTÍNEZ, E., 2017 - Secuencia de cerámica paracas en Pallaucha, Vilcashuamán-Ayacucho. Boletín de Arqueología PUCP, 22: 91-116.

MENDOZA MARTÍNEZ, E., 2018 - El periodo formativo tardío y final en Ayacucho, con una perspectiva desde Pallaucha-Vilcashuamán, 324 pp.; Lima: Pontificia Universidad Católica del Perú (PUCP). Tesis de maestría.

MENDOZA MARTÍNEZ, E. \& VIVANCO POMACANCHARI, C., 2019 - Tukri-Apu Urqu, Un sitio con arquitectura en forma de " $U$ " en la cuenca del río Pampas, Cangallo, Ayacucho. In: Actas del IV Congreso Nacional de Arqueología (Volumen II): 55-65; Lima: Ministerio de Cultura.

MENZEL, D., ROWE, J. H. \& DAWSON, L. E., 1964 - The Paracas Pottery of Ica: A Study in Style and Time, 399 pp.; Berkeley: University of California Press.

NESBITT, J., IBARRA ASENCIOS, B. \& TOKANAI, F., 2020 - The Architecture and Chronology of Reparin, Eastern Ancash, Peru. Nawpa Pacha: Journal of Andean Archaeology, 40 (1): 41-59.

NESBITT, J., JOHNSON, R. \& HOROWITZ, R. A., 2019 - Was Obsidian Used for Camelid Shearing in Ancient Peru? An Experimental and Use-Wear Study. Ethnoarchaeology: Journal of Archaeological, Ethnographic and Experimental Studies, 11 (1): 80-94.

NESBITT, J. \& MATSUMOTO, Y., 2014 - Cupisnique Pottery at the South Highland Site of Campanayuq Rumi: Implications for Late Initial Period Interaction. Peruvian Archaeology, 1: 47-61.

NESBITT, J., MATSUMOTO, Y. \& CAVERO PALOMINO, Y., 2019 - Campanayuq Rumi and Arpiri: Two Civic-Ceremonial Centers on the Southern Periphery of the Chavín Interaction Sphere. Nawpa Pacha: Journal of Andean Archaeology, 39 (1): 57-75. 
OCHATOMA PARAVICINO, J., 1998 - El Periodo Formativo en Ayacucho: balances y perspectivas. Boletín de Arqueología PUCP, 2: 289-302.

PERÉZCALDERON, I. \& PAREDES HUARCAYA, H., 2016 - Excavaciones en Waychaupampa, poblado del periodo Formativo en Ayacucho. Arqueología y Sociedad, 32: 497-516.

PERÉZ, I., PURIZAGA VEGA, M. \& LEÓN, F., 2007 - Vilcashuamán: paisaje, historia y cultura, 212 pp.; Ayacucho: Universidad San Cristóbal de Huamanga (UNSCH), Oficina de Investigación.

RADEMAKER, K., GLASCOCK, M. D., KAISER, B., GIBSON, D., LUX, D. R. \& YATES, M. G., 2013 - Multi-Technique Geochemical Characterization of the Alca Obsidian Source, Peruvian Andes. Geology, 41 (7): 779-782.

REINDEL, M., ISLA, J., GORBAHN, H. \& OTTEN, H., 2015 - Paracas en Palpa: los fundamentos del poder de la cultura Nasca. Peruvian Archaeology, 2: 37-64.

RICK, J. W., 2017 - The Nature of Ritual Space at Chavín de Huántar. In: Rituals of the Past: Prehispanic and Colonial Case Studies in Andean Archaeology (S. A. Rosenfeld \& S. L. Bautista, eds.): 21-49; Boulder: University Press of Colorado.

RICK, J. W., MESÍA, C., CONTRERAS, D., KEMBEL, S. R., RICK, R. M., SAYRE, M. \& WOLF, J., 2009 - La cronología de Chavín de Huántar y sus implicancias para el Periodo Formativo. Boletín de Arqueología PUCP, 13: 87-132.

SILVERMAN, H., 1994 - Paracas in Nazca: New Data on the Early Horizon Occupation of the Rio Grande de Nazca Drainage, Peru. Latin American Antiquity, 5 (4): 359-382.

SILVERMAN, H., 1996 - The Formative Period on the South Coast of Peru: A Critical Review. Journal of World Prehistory, 10 (2): 95-146.

SOßNA, V., 2015 - Climate and Settlement in Southern Peru: The Northern Río Grande de Nasca Drainage Between 1500 BCE and 1532 CE, 317 pp.; Wiesbaden: Reichert Verlag, Forschungen zur Archäologie Außereuropäischer Kulturen (Book 13).

TRIPCEVICH, N. \& CONTRERAS, D. A., 2011 - Quarrying Evidence at the Quispisisa Obsidian Source, Ayacucho, Peru. Latin American Antiquity, 22 (1): 121-136.

TRIPCEVICH, N. \& CONTRERAS, D. A., 2013 - Archaeological Approaches to Obsidian Quarries: Investigations at the Quispisisa Source. In: Mining and Quarrying in the Ancient Andes. Sociopolitical, Economic and Symbolic Dimensions (N. Tripcevich \& K. J. Vaughn, eds.): 23-44; Nueva York: Springer.

UNKEL, I., REINDEL, M., GORBAHN, H., ISLA CUADRADO, J., KROMER, B. \& SOBNA, V., 2012 - A Comprehensive Numerical Chronology for the pre-Columbian Cultures of the Palpa Valleys, South Coast of Peru. Journal of Archaeological Science, 39 (7): 2294-2303.

VAN GIJSEGHEM, H., 2006 - A Frontier Perspective on Paracas Society and Nasca Ethnogenesis. Latin American Antiquity, 17 (4): 419-444.

VAUGHN, K. J. \& GLASCOCK, M. D., 2005 - Exchange of Quispisisa Obsidian in Nasca: New Evidence from Marcaya. Andean Past, 7: 93-110.

YOUNG, M., 2017 - De la montaña al mar: intercambio entre la sierra centro-sur y la costa sur en el Horizonte Temprano. Boletín de Arqueología PUCP, 22: 9-34. 